University of Pittsburgh School of Law

Scholarship@PITT LAW

Articles

Faculty Publications

2011

\title{
The Rome I Regulation Rules on Party Autonomy for Choice of Law: A U.S. Perspective
}

Ronald A. Brand

University of Pittsburgh School of Law, rbrand@pitt.edu

Follow this and additional works at: https://scholarship.law.pitt.edu/fac_articles

Part of the Commercial Law Commons, Comparative and Foreign Law Commons, Conflict of Laws Commons, Consumer Protection Law Commons, Contracts Commons, Dispute Resolution and Arbitration Commons, European Law Commons, International Law Commons, International Relations Commons, International Trade Law Commons, Jurisdiction Commons, Jurisprudence Commons, Law and Economics Commons, Law and Society Commons, Litigation Commons, Political Economy Commons, and the Rule of Law Commons

\section{Recommended Citation}

Ronald A. Brand, The Rome I Regulation Rules on Party Autonomy for Choice of Law: A U.S. Perspective, Unpublished (2011).

Available at: https://scholarship.law.pitt.edu/fac_articles/454

This Article is brought to you for free and open access by the Faculty Publications at Scholarship@PITT LAW. It has been accepted for inclusion in Articles by an authorized administrator of Scholarship@PITT LAW. For more information, please contact leers@pitt.edu, shephard@pitt.edu. 


\section{Rome I's Rules on Party Autonomy for Choice of Law: \\ A U.S. Perspective \\ Ronald A. Brand* \\ Discussion draft - not for citation or further distribution}

[F]reedom of contract is an essential part of the market economy..... No State can hope effectively to control international contracts.

Peter Nygh, Autonomy in International Contracts (1999)

Table of Contents

I. Introduction

II. Party Autonomy: The Interests and Approaches

A. Should states allow party autonomy in choice of law?

1. General considerations

2. The Party Autonomy Rule in the United States

a. The Restatement (Second) Conflict of Laws: The "No Substantial Relationship" Test

b. The Uniform Commercial Code: The "Reasonable Relation" Test

c. Case Law

3. The Rome I Regulation

B. If party autonomy is allowed, what (if any) limits are appropriate?

1. General Comparisons

*Professor of Law and Director, Center for International Legal Education, University of Pittsburgh School of Law. I am particularly grateful for the insights shared by Professor Volker Behr and the research assistance of Katherine Lampron and Alexandra Williams. 
2. Limitations on Party Autonomy in the United States

3. Limitations on Party Autonomy in the Rome I Regulation

a. Pubic Policy and Mandatory Rules in the Rome I Regulation

1) Terminology and Substance: Understanding the Rome I Distinctions Within the Realm of Public Policy

2) Provisions of the law which cannot be derogated from by agreement

3) Overriding Mandatory Provisions

4) Restating the Mandatory Rules Provisions and Understanding Their Application

c. Protection of Specific Categories of Persons in the Rome I Regulation

d. Public Policy Generally

III. When and how should choice of law rules be used to protect specific classes of persons?

A. What is the appropriate threshold at which the protection of private interests through allowing party autonomy should give way to public interests in protecting weaker parties in a relationship?

1. Rome I and the Rationale for Protection of Consumers

2. Comparing Approaches to the Use of Private International in the Public Interest in Protecting Consumers

a. Japan's New Private International Law Rules

b, OAS Negotiations

B. Are private international law rules the appropriate tool for consumer protection?: Another look at U.S. law

1. Reconsidering U.S. Limits on Party Autonomy 
2. Consumer Protection Outside of Private International Law

3. Considering the Alternatives
a. Consumer Protection Through Economic Analysis
b. Consumer Protection Through Alternative Dispute Resolution

\section{Introduction}

It is, for several reasons, a rather daunting task for someone from the United States to provide comments at a conference in an EU Member State on the Rome I Regulation, ${ }^{1}$ even when those comments are limited (as are mine) to the topic of party autonomy in choice of law. First of all, while much comment on U.S. law on conflicts is focused on the easily accessible Restatement (Second) Conflict of Laws, conflicts law in the United States remains a matter of common law, and - unlike the Europe of recent developments - in the United States, conflicts law remains a matter of state, rather than federal, law. Thus, two very different systemic foundations define this area of private international law on the two sides of the Atlantic. A second reason for caution in comparing the law on party autonomy for choice of law in contractual relationships is that the structure of the approaches taken and rules applied are different enough on the two sides of the Atlantic to counsel a justified reticence in either making comparisons or offering general comment.

Despite these very rational reasons for avoiding comment on the difference in rules on

${ }^{1}$ Regulation (EC) No 593/2008 of the European Parliament and of the Council of 17 June 2008 on the law applicable to contractual obligations (Rome I), O.J. Eur. Union, L 177/6, 4 July 2008. 
party autonomy in the United States and Europe, I have accepted the invitation to provide an American perspective on this aspect of the Rome I Regulation. My approach here is to consider a set of questions about party autonomy in choice of law. These questions focus on the interests we should seek to protect and advance in developing the rules governing party choice of law. With each question, my goal is to consider the state of the law on party autonomy for choice of law in the United States, and that in Europe represented by the Rome I Regulation. This process, I hope, demonstrates some of the similarities and differences between the law in the United States and Europe. What I do not do is to try to determine which is necessarily the better approach. I instead hope that raising the questions, and discussing the differences, might in some way help us each understand our own law better.

In the end, I focus on the rules of the Rome I Regulation dealing with consumer contracts, and the limits those rules place on party autonomy. At this point, I will expand the discussion by noting the new rules on choice of law found in Japan's law on conflict of laws, and recent proposals for instruments within the framework of the Organization of American States. My purpose here, as earlier in the discussion, is not to come to clear conclusions on what the right or wrong approach is, but rather to note the differences in approach and invite further consideration of those differences.

\section{Party Autonomy: The Interests and Approaches}

\section{A. Should states allow party autonomy in choice of law?}

\section{General considerations}

The most fundamental question is whether a legal system should allow private parties any 
freedom of choice in determining in the law applicable to their relationships with other private parties. In his post-Hague Lecture writings, the late Peter Nygh echoed the current state of commentary on this question, stating that "freedom of contract is an essential part of the market economy," and that "[n]o State can hope effectively to control international contracts." Like many commentators, ${ }^{3}$ in these statements and others, Nygh signaled that the age of governmental prevention of party autonomy is a thing of the past.

The concept of party autonomy in the study of private international law affects two important matters: choice of forum and choice of law. While the Rome I Regulation deals only with choice of law, cases and commentary tend often to lump the two together. Thus, in considering the historical development of party autonomy for choice of law, one must necessarily consider as well the development for purposes of choice of forum.

General freedom of contract developed largely in the nineteenth and twentieth centuries, with the private contract, "originally ... seen as an obligation imposed on the parties by the general law arising out of their transaction," coming to be seen as "an obligation created by the parties themselves." ${ }^{\prime 4}$ The move to a general rule of party autonomy was gradual not abrupt, and was foreshadowed by such decisions as Robinson v. Bland, ${ }^{5}$ and Pritchard v. Norton. ${ }^{6}$ In the first of these cases, Lord Mansfield suggested that, when one Englishman lent money to another

\footnotetext{
${ }^{2}$ Peter NyGH, AUTONOMY IN INTERNATIONAL CONTRACTS 2 (1999). 3

${ }^{4}$ NyGH supra note _, at 7, citing P.S. ATIYAH, THE RISE AND FALL OF FREEDOM OF CONTRACT $141 \& 420$ (Oxford University Press, 1979).
}

${ }^{5} 2$ Burr. 1077 (1760).

${ }^{6} 106$ U.S. 134 (1882). 
Englishman in Paris, the lex loci contractus would not apply because of the implied fiction that "the parties had a view to the law of England." In the latter case, the U.S. Supreme Court stated that " $[t]$ he law we are in search of ... is that which the parties have, either expressly or presumptively, incorporated into their contract as constituting its obligation."»

As contract analysis moved from a focus on consideration of the impact of the parties' agreement under the law to a focus on the subjective intent of the parties, the idea that obligations were fixed (but could be affected by the parties), turned to analysis of the contract as the starting point, (with the law outside the contract providing exceptions beyond which the parties could not express a contrary intent). In other words, legal systems moved from obligations in the law that could be affected by private relationships to considering private agreements as the source of the "law" applicable to a relationship, with the general legal structure providing limitations on how far the parties could go with their own "law."

\section{The Party Autonomy Rule in the United States}

\section{a. The Restatement (Second) Conflict of Laws: The "No Substantial Relationship" Test}

In the United States, this evolution from legal obligation supplemented by private contract, to private law of the contract limited by legal obligation is often associated with changes found in a comparison of the First and Second Restatements on the Conflict of Laws. In

${ }^{7} 2$ Burr. at

${ }^{8} 106$ U.S. at 136.

${ }^{9}$ See NyGH, supra note 2, at 7-13. See also Patrick J. Borchers, Categorical Exceptions to Party Autonomy in Private International Law, 82 Tul. L. Rev. 1645, 1647-49 (2008) 
the First Restatement, section 332, titled "Law Governing Validity of Contract," makes no reference to a law chosen by the parties, and only provides a list of those issues in respect of which "[t]he law of the place of contracting determines the validity and effect of a promise." 10 This was replaced in the Second Restatement by sections 186 and 187, which specifically authorize party autonomy, with limitations:

\section{§ 186. Applicable Law}

Issues in contract are determined by the law chosen by the parties in accordance with the rule of $\S 187$ and otherwise by the law selected in accordance with the rule of $\S 188$ [Law Governing in Absence of Effective Choice by the Parties].

\section{$\S 187$. Law of the State Chosen by the Parties}

(1) The law of the state chosen by the parties to govern their contractual rights and duties will be applied if the particular issue is one which the parties could have resolved by an explicit provision in their agreement directed to that issue.

\footnotetext{
${ }^{10}$ Restatement, Conflict Of LAws $\S 332$ (1934). See Symeon C. Symeonides, "The First Conflicts Restatement Through the Eyes of Old: As Bad as its Reputation?," Southern Illinois University Law Journal, Vol. 32 (2007), pp. $72-73$ (noting that, the First Restatement's lack of adherence to the concept of party autonomy did not reflect early American cases that supported the concept, but was probably a result of the political and legal convictions of Joseph $\mathrm{H}$. Beale, who largely determined the course of the First Restatement). Commentators dealing with the history of choice of law in the United States tend to focus on choice of forum, assuming that the development of judicial respect for both choice of forum and choice of law clauses has been parallel. See, e.g., Linda S. Mullinix, "Another Choice of Forum, Another Choice of Law: Consensual Adjudicatory Procedure in Federal Court," 42 Fordham L. Rev. 291, 293(Dec. 1988, No. 3) ("The ability of prospective litigants to choose in advance both the court that will hear the case and the law that will govern the dispute now enjoys widespread approval in federal courts. This was not always so. Indeed, the current doctrine of consensual adjudicatory procedure represents a wholesale abandonment of a 100-year taboo against party autonomy in procedural matters." citing Home Ins. Co. of New York v. Morse, 77 U.S. 445, 451 (1874), which dealt only with choice of forum clauses in stating that "agreements in advance to oust the courts of the jurisdiction conferred by law are illegal and void."). Compare Eugene F. Scoles \& Peter Hay, Conflict of Laws 659 (2d ed. 1992) ("Historically, party autonomy has support in the caselaw dating back well into the nineteenth century," citing Pritchard v. Norton, 106 U.S. 124 (1882) (implied choice of law based on intent of the parties) and Dolan v. Mutual Reserve Fund Life Association, 173 Mass. 197, 53 N.E. 398 (1899) (honoring express choice of law by the parties)).
} 
(2) The law of the state chosen by the parties to govern their contractual rights and duties will be applied, even if the particular issue is one which the parties could not have resolved by an explicit provision in their agreement directed to that issue, unless either

(a) the chosen state has no substantial relationship to the parties or the transaction and there is no other reasonable basis for the parties' choice, or

(b) application of the law of the chosen state would be contrary to a fundamental policy of a state which has a materially greater interest than the chosen state in the determination of the particular issue and which, under the rule of $\S 188$, would be the state of the applicable law in the absence of an effective choice of law by the parties.

(3) In the absence of a contrary indication of intention, the reference is to the local law of the state of the chosen law. ${ }^{11}$

Under the Second Restatement, when parties could have written specific rules into the contract, achieving the same result by selecting the law of a particular state will be allowed. This follows the idea that the contract creates the law, and that parties can write that law either explicitly in the contract or by incorporating the law of a specific state. Subsection (2) of section 187 goes further by providing that the parties' choice of law will govern, even when the issue is not one for which the parties could have written an explicit provision into their contract, unless either (a) there is lack of either a "substantial relationship" between the parties, or their transaction, and the chosen state, or another "reasonable basis" for their choice of law, or (b) application of the chosen law "would be contrary to a fundamental policy of a state which has a materially greater interest" in the dispute.

Thus, the Restatement (Second), which is widely followed in the United States, clearly comes down on the side of allowing party autonomy, but sets forth some limitations on that autonomy. Thus, mandatory rules of the forum (i.e., the law that determines issues which the

\footnotetext{
${ }^{11}$ RESTATEMENT (SECOND) CONFLICT OF LAWS $§ \S 186,187$ (1971).
} 
parties could not have resolved by an explicit provision in their agreement) may be applied, unless there is a substantial relationship between the parties or the transaction and the state of the chosen law. Moreover, even if there is a substantial relationship to the state of the chosen law, public policy may intervene. Thus, if "the law of the chosen state would be contrary to a fundamental policy of a state which has a materially greater interest than the chosen state," the chosen law may be trumped by the law of the state with the materially greater interest.

One problem for both contract drafters and courts is in determining just what the limits are and when they apply. In addition, unlike the Rome I Regulation, and laws in other civil law countries, the Restatement does not provide specific rules to protect categories of parties such as consumers, employees, or insureds.

\section{b. The Uniform Commercial Code: The "Reasonable Relation" Test}

Before going on to a comparison with European law on party autonomy, it is useful to review the other major U.S. source of a rule on party autonomy in selecting the law governing contractual relationships. That source is the Uniform Commercial Code (UCC). Like the Restatement, the UCC begins with a statement of respect for party autonomy, followed by limitations. The UCC rule has been the source of recent development, so it is worth tracking that development.

The original UCC of 1956 contained section 1-105, which provided that when a transaction bears a reasonable relation to this state and also to another state or nation, parties may agree that the law of either this state or of such other state or nation shall govern their rights and duties. Failing such agreement, this Act applies to 
transactions bearing an appropriate relation to this state. ${ }^{12}$

When Article I of the UCC was revised in 2001, this rule was replaced with a new section 1-301, which split the rule, providing complete freedom for choice of law in merchant-to-merchant contracts (deleting the "reasonable relation" requirement), and setting forth specific, expanded limitations on choice of law in consumer contracts. ${ }^{13}$ The general rule of this provision is contained in paragraph (b), which reads:

b) Except as otherwise provided in this section:

(1) an agreement by parties to a domestic transaction that any or all of their rights and obligations are to be determined by the law of this State or of another State is effective, whether or not the transaction bears a relation to the State designated; and

(2) an agreement by parties to an international transaction that any or all of their rights and obligations are to be determined by the law of this State or of another State or country is effective, whether or not the transaction bears a relation to the State or country designated. ${ }^{14}$

In paragraph (e), this rule of party autonomy became subject to a public policy limitation:

(e) An agreement otherwise effective under subsection (b) is not effective to the extent that application of the law of the State or country designated would be contrary to a fundamental policy of the State or country whose law would govern in the absence of agreement under subsection (c).

The UCC provision did not contain any general reference to mandatory rules-except to the extent those mandatory rules would rise to the level of public policy. It did, however, contain a separate rule for consumer contracts that incorporated concepts of mandatory rules and followed the European model found at the time in the Rome I Convention, and now found in the Rome I

\footnotetext{
${ }^{12}$ Uniform Commercial Code (1956 version) § 1-105(1).

${ }^{13}$ Uniform Commercial Code (2001 version) § 1-301.

${ }^{14} I d$.
} 
Regulation. Paragraph (d) of section 1-301 stated:

(d) If one of the parties to a transaction is a consumer, the following rules apply: (1) An agreement referred to in subsection (b) is not effective unless the transaction bears a reasonable relation to the State or country designated.

(2) Application of the law of the State or country determined pursuant to subsection (b) or (c) may not deprive the consumer of the protection of any rule of law, that both is protective of consumers and may not be varied by agreement, of the State or country:

(A) in which the consumer habitually resides, unless subparagraph (B) applies; or

(B) if the transaction is a sale of goods, in which the consumer makes the contract and takes delivery of those goods, if such State or country is not the State or country in which the consumer habitually resides.

Thus, a consumer would have been allowed to enter into a valid choice of law clause when the transaction bore a "reasonable relation" to the forum state, but would retain any mandatory rule protections of both the consumer's state of habitual residence and (in sale of goods contracts) the state of performance.

The first thirty-three states to enact the revised Article 1 all chose not to include the new section 1-301, and instead retained the substance of the former section 1-105. ${ }^{15}$ As a result of this clear rejection of the "uniform" rule, the National Conference of Commissioners on Uniform State Laws and the American Law Institute (ALI) amended the Official Text of section 1-301 in 2008 so that it reverted to the language of the former section 1-105, which had remained the de facto uniform rule. ${ }^{16}$

${ }^{15}$ The Virgin Islands was the only jurisdiction to enact the revised $\S 1-301$. See, The American Law Institute, $85^{\text {th }}$ Annual Meeting Program, May 19-21-2008, p. 8, n. 3; Keith A. Rowley, The Often Imitated, But (Still) Not Yet Duplicated, Revised UCC Article 1," available at http://www.law.unlv.edu/faculty/rowley/ra1_updates.htm.

${ }^{16}$ American Law Institute, $85^{\text {th }}$ Annual Meeting Program, supra note 11, p. 8. The current version of $\S 1-301$ reads as follows: 


\section{c. Case Law}

Case law in the United States follows the Restatement and UCC approach of seeking some relationship between the chosen law and the transaction. ${ }^{17}$ This limitation demonstrates a concern that the choice of an unconnected law could allow parties to purely local transactions to avoid local law. ${ }^{18}$ In this respect, Section 187 of the Second Restatement is largely representative of American case law. ${ }^{19}$ The Section 187 requirement that the chosen state law must have a "substantial relationship to the parties or the transaction" when mandatory rules are involved has not resulted in a more stringent test than is generally found in the case law. ${ }^{20}$

The relationship connection will likely not be satisfied if the place of contract formation

§ 1-301. Territorial Applicability; Parties' Power to Choose Applicable Law

(a) Except as otherwise provided in this section, when a transaction bears a reasonable relation to this state and also to another state or naation the parties may agree that the law either of this state or of such other state or nation shall govern their rights and duties,

(b) In the absence of an agreement effective under subsection (a), and except as provided in subsection (c), [the Uniform Commercial Code] applies to transactions bearing an appropriate relation to this state.

(c) [listing UCC provisions from which derogation is not allowed]

${ }^{17}$ EugenE F. SCOLES ET AL., CONFLICT OF LAWS, $§ 18.6$ (3d ed. 2000); Armstrong v. Accrediting Council for Cont. Educ. \& Trng, Inc., 177 F.3d 1036 (D.C. Cir. 1999) ("substantial nexus to this transaction"); Consolidated Jewelers, Inc. v. Std. Financial Corp., 325 F.2d 31, 34 ( $6^{\text {th }}$ Cir. 1963 ( share a "vital element"); Owens v. Hagenbeck-Wallace Shows Co., 58 R.I. 162, 192 A. 163-64 (1937) ("real relation").

${ }^{18}$ EugENE F. SCOLES ET AL., CONFLICT OF LAWS, § 18.6 (3d ed. 2000); Crawford v. Seattle, Renton \& So. Railway Co., 86 Wash. 628, 150 P. 1155, 1157 (1915). But see Waytt v. Fulrath, 16 N.Y.3d 169, 264 N.Y.S.2d 233, 211 N.E.2d 637 (1965).

${ }^{19}$ Restatement (Second) Conflict of Laws $\$ 187$ (1971).

${ }^{20}$ EUGENE F. SCOLES ET AL., supra note _, at $\S 18.6$ (3d ed. 2000); Gamer v. duPont Glore Forgan, Inc., 65 Cal.App.3d 280, 290, 135 Cal. Rptr. 230 (1976); Reger v. Nat'1 Assoc. of Bedding Manuf. Group Ins. Trust Fund, 83, Misc.2d 527, 539-40, 372 N.Y.S.2d 97 (1975). 
and the place of performance are in the same place, and a different state's law is chosen. ${ }^{21}$ The parties are free, however, to select the law of the state that is the domicile of one of them and either the place of the performance or the place of formation. ${ }^{22}$ The alternate test under Restatement section 187(2)(a), supporting party choice upon the finding of a "reasonable basis for the parties' choice," will result in upholding their choice despite the relevant relationship if, for example, the law chosen is particularly well-developed in the type of transaction involved, or if the parties have more familiarity with the chosen law. ${ }^{23}$

\section{The Rome I Regulation}

The Rome I Regulation begins the party autonomy analysis with the same rule found in the Second Restatement. Parties to a contract have general freedom to choose the applicable law. This general rule is found in the first two paragraphs of Article 3:

\section{Article 3}

Freedom of choice

1. A contract shall be governed by the law chosen by the parties. The choice shall be made expressly or clearly demonstrated by the terms of the contract or the circumstances of the case. By their choice the parties can select the law applicable to the whole or to part only of the contract.

2. The parties may at any time agree to subject the contract to a law other than that which previously governed it, whether as a result of an earlier choice made under this Article or of other provisions of this Regulation. Any change in the law to be applied that is made after the conclusion of the contract shall not prejudice its formal validity under Article 11 or adversely affect the rights of third parties.

Thus, the rule of party autonomy in choice of law exists for both initial agreements, partial

\footnotetext{
${ }^{21}$ EUGENE F. SCOLES ET AL., CONFLICT OF LAWS, $§ 18.6$ (3d ed. 2000).

${ }^{22} I d$.

${ }^{23}$ EUGENE F. SCOLES ET AL., supra note _, at $\S 18.10$.
} 
agreements, and amendments to either of them. Paragraph (2) recognizes the existence of formal validity requirements in Article 11, and prevents any amendments to the choice of law agreement from "adversely affect[ing] the rights of third parties," interestingly inserting the first limitations on party autonomy in the statement of the rule itself. This leads us to the second important question in considering party autonomy in choice of law: what limits are appropriate to a basic rule of party autonomy?

\section{B. If party autonomy is allowed, what (if any) limits are appropriate?}

\section{General Comparisons}

As the rule of the Second Restatement indicates, the move to respect for party autonomy has not been without the retention of limitations on that autonomy. ${ }^{24}$ This is true in both the United States and Europe, but the limitations have been defined and developed in rather different ways.

The most striking differences in U.S. and European law on choice of law have already been mentioned. While the Rome I Regulation centralizes the rules of choice of law in contractual matters for all European Union Member States in a civil code-type document, ${ }^{25}$ U.S. law on choice of law remains fragmented by remaining a matter of state law, and less

\footnotetext{
${ }^{24}$ One could argue that a general rule of party autonomy in choice of law, accompanied by specific limitations on such freedom of contract, may not bring different results than would a general rule that parties cannot choose the law governing their contract, except in certain situations. The results may be the same even if the starting point and analysis differ. Thus, the evolution from the latter of these positions to the former, may be less of a revolution in choice of law than one might at first perceive.

${ }^{25}$ While Ireland has indicated its intention to adopt and apply Rome I, Denmark and the United Kingdom are not bound by it. Rome I Regulation, supra note 1, recitals 44-46.
} 
particularized because of its development as common law in the courts. ${ }^{26}$ Thus, any comparison requires caveats resulting from both the greater fragmentation and diminished certainty of U.S. law. Nonetheless, the Second Restatement (even though now more than thirty years old) continues to provide a reasonably accurate statement of U.S. law. ${ }^{27}$

\section{Limitations on Party Autonomy in the United States}

While U.S. law is at least theoretically more fragmented than European Law, it tends to approach the issue of party autonomy with analysis that is somewhat less complicated in structure than the framework provided in the Rome I Regulation. Thus, while both U.S. law and Rome I begin with the assumption of party autonomy, the limitations appear more complicated and diverse in Rome I. In the United States, the principal limit on party autonomy in choice of law is public policy. What we gain by having fewer limitations, however, is perhaps lost, in part, by the fact that the role of public policy in addressing party autonomy for choice of law is rather amorphous.

At one time, it seemed that the public policy limitation could be explained by a private law/public law distinction, with parties to a choice of law clause having free rein on private law matters, but not being able to opt out of certain public law rules. Thus,

[t]raditionally, the scope of this autonomy has been confined to matters that otherwise would be governed by private law, which in the context of commerce essentially means the main body of contract law. Within this context, parties to international contracts are free to designate the law or principles that will govern their

\footnotetext{
${ }^{26}$ Some states have adopted private international law statutes. See, e.g. [Louisiana and Oregon] 
transaction to the exclusion of all otherwise applicable law. They are also free to arbitrate privately any disputes that might arise among them to the exclusion of otherwise compulsory public court litigation. Matters governed by public law, such as antitrust, securities, and environmental laws, traditionally have been outside the scope of private autonomy of contract. Public law typically has applied irrespective of private choice, and claims arising under public law traditionally have been subject to resolution exclusively in the courts of the nation supplying the law. ${ }^{28}$

In this approach, public policy was defined in part by what might have been considered to be the mandatory rules of public law. ${ }^{29}$ There also existed some tendency to protect weaker parties in certain relationships. ${ }^{30}$ These limitations on party autonomy were largely diminished, however, with U.S. Supreme Court decisions such as Bremen v. Zapata (enforcing a choice of forum clause between U.S. and Italian parties choosing a London court), ${ }^{31}$ Mitsubishi Motors Corp. v. Soler Chrysler-Plymouth (enforcing an agreement to arbitrate antitrust matters in Japan), ${ }^{32}$ and Carnival Cruise Lines, Inc. v. Shute (enforcing a small print choice of court clause on the back of a consumer cruise ticket). ${ }^{33}$

These cases help demonstrate that the public policy limitation in the United States is indeed a narrow one. While proposed section 1-301 of the UCC has been subsequently in favor

${ }^{28}$ Philip J. McConnaughay, The Scope of Autonomy in International Contracts and Its Relation to Economic Regulation and Development, 39 COLUM. J. TRANSNAT'L L. 595, 597-98 (2001) (footnotes omitted).

${ }^{29}$ See Borchers, supra note _, at 1647.

${ }^{30}$ See, e.g., See Edward A. Purcell, Jr., Geography as a Litigation Weapon: Consumers, Forum-Selection Clauses, and the Rehnquist Court, 40 UCLA L. REV. 423, 459-71 (1992).

${ }^{31} \mathrm{M} / \mathrm{S} /$ Bremen and Unterweser Reederei, GmbH v. Zapata Off-Shore Co., 407 U.S. 1 (1972).

$$
\begin{aligned}
& { }^{32} 473 \text { U.S. } 614 \text { (1985). } \\
& { }^{33} 499 \text { U.S. } 972 \text { (1991). }
\end{aligned}
$$


of language consistent with the former section $1-105,{ }^{34}$ the comments to the proposed section remain relevant. Comment 6 to that provision, consistent with comment e to Restatement (Second) section $187,{ }^{35}$ provides:

Under the fundamental policy doctrine, a court should not refrain from applying the designated law merely because this would lead to a result different than would be obtained under the local law of the State or country whose law would otherwise govern. Rather, the difference must be contrary to a public policy that is so substantial that it justifies overriding the concerns for certainty and predictability underlying modern commercial law as well as concerns for judicial economy generally. Thus, application of the designated law will rarely be found to be contrary to a fundamental policy of the State or country whose law would otherwise govern when the difference between the two concerns a requirement, such as a statute of frauds, that relates to formalities, or general rules of contract law, such as those concerned with the need for consideration. ${ }^{36}$

The UCC comment continues by noting the following oft-quoted language from Judge Cardozo's opinion in Loucks v. Standard Oil Co. of New York, ${ }^{37}$ which deals with when the forum state's law will trump the law of another state under the public policy doctrine:

Our own scheme of legislation may be different. We may even have no legislation on the subject. That is not enough to show that public policy forbids us to enforce the foreign right. A right of action is property. If a foreign statute gives the right, the mere fact that we do not give a like right is no reason for refusing to help the plaintiff in getting what belongs to him. We are not so provincial as to say that every solution of a problem is wrong because we deal with it otherwise at home. Similarity of legislation has indeed this importance; its presence shows beyond question that the foreign statute does not offend the local policy. But its absence does not prove the contrary. It is not to be exalted into an indispensable condition. The misleading word 'comity' has been responsible for much of the trouble. It has been fertile in suggesting a discretion unregulated by general principles.

The courts are not free to refuse to enforce a foreign right at the pleasure of the judges, to suit the individual notion of expediency or fairness. They do not close their

\footnotetext{
${ }^{34}$ See, supra, notes ___ a and accompanying text.

35

${ }^{36} \mathrm{UCC} \S 1-301($

${ }^{37} 120$ N.E. 198 (1918).
} 
doors, unless help would violate some fundamental principle of justice, some prevalent conception of good morals, some deep-rooted tradition of the common weal. ${ }^{38}$

Finally, comment 6 to the rejected section 1-301 deals with the distinction between mandatory rules and public policy found in the Rome I Regulation. Indicating that, in the United States, this distinction is less significant than in the Rome I Regulation, the comment states:

Analytically, one might conclude that application of the designated law is contrary to a fundamental policy of the State or country whose law would otherwise govern either (i) because the substance of the designated law violates a fundamental principle of justice of that State or country or (ii) because it differs from a rule of that State or country that is "mandatory" in that it must be applied in the courts of that State or country without regard to otherwise-applicable choice of law rules of that State or country and without regard to whether the designated law is otherwise offensive. This distinction, which may have more theoretical than practical significance, has been suggested in some international conventions in this area, although in some cases the concept is applied to authorize the forum State to apply its mandatory rules, rather than those of the State or country whose law would otherwise govern. The latter situation is not addressed by this section. ${ }^{39}$

\section{Limitations on Party Autonomy in the Rome I Regulation}

It is largely in the quantity and structure of the limitations on party autonomy for choice of law that the Rome I Regulation becomes rather befuddling to the U.S. observer. While one article states the rule of party autonomy, limitations on that autonomy are found in at least nine articles $(3,5,6,7,8,9,11,13$, and 21), with further elaboration of these limitations provided in many of the 46 recitals preceding the Regulation text. Thus, while the Regulation is set forth in the format of a civil law text (and does follow the pre-existing Rome I Convention), one must ask whether the often nuanced and sometimes confusing interrelationship of its articles (at least on the surface) provides the usual clarity and predictability one would hope to achieve in such an

\footnotetext{
${ }^{38} 120$ N.E. at $201-02$ (citations omitted).

${ }^{39} \mathrm{UCC} \S 1-301($
} 
instrument.

\section{a. Pubic Policy and Mandatory Rules in the Rome I Regulation}

Rome I contains three terms that deal in some manner with matters related to public policy. These are "provisions of the law which cannot be derogated from by agreement," “overriding mandatory provisions," and "public policy." The initial question one has when reading Rome I is what is the rationale for using different terms, and what substantive differences they are meant to delineate.

\section{1) Terminology and Substance: Understanding the Rome I Distinctions Within the Realm of Public Policy}

According to Lando and Nielsen, writing prior to the date on which the Regulation was finalized, both "provisions of the law which cannot be derogated from by agreement" and “overriding mandatory provisions" are intended to refer to mandatory rules of law. ${ }^{40}$ Recital 37 of the final Regulation states that " $[\mathrm{t}]$ he concept of 'overriding mandatory provisions' should be distinguished from the expression 'provisions which cannot be derogated from by agreement' and should be construed more restrictively."41 Given the use of the phrase "overriding mandatory

${ }^{40}$ Ole Lando \& Peter Arnt Nielsen, The Rome I Regulation, 45 COMMON MKT. L. REV. $1687,1718-24$ (2008).

${ }^{41}$ Rome I, supra note 2 , recital 37 . The entirety of recital 37 raises some question about whether "provisions of law which cannot be derogated from by agreement" is intended to be an element of public policy. That provision reads as follows:

Considerations of public interest justify giving the courts of the Member States the possibility, in exceptional circumstances, of applying exceptions based on public policy and overriding mandatory provisions. The concept of 'overriding mandatory provisions' 
provisions" (and not just simply "mandatory provisions") one can assume that the Lando and Nielsen interpretation is consistent with the final Regulation. Thus, "overriding mandatory provisions" is intended as a subcategory of all mandatory provisions, and "provisions which cannot be derogated from by agreement" designates either a subcategory of or a category coextensive with the realm of all mandatory provisions. Either way, "provisions which cannot be derogated from by agreement" would appear to include all "overriding mandatory provisions."

The important point seems to be that "provisions which cannot be derogated from by agreement" is the larger category, and that "overriding mandatory provisions" is the more important subcategory; both referring to mandatory rules.

\section{2) Provisions of the law which cannot be derogated from by agreement}

Paragraphs (3) and (4) of Article 3 limit party autonomy by providing the following rules:

3. Where all other elements relevant to the situation at the time of the choice are located in a country other than the country whose law has been chosen, the choice of the parties shall not prejudice the application of provisions of the law of that other country which cannot be derogated from by agreement.

4. Where all other elements relevant to the situation at the time of the choice are

should be distinguished from the expression 'provisions which cannot be derogated from by agreement' and should be construed more restrictively.

Thus, while "overriding mandatory provisions" clearly are to be applied based on "considerations of public policy." It would seem that the same could be (although it is not explicitly) said for "provisions which cannot be derogated from by agreement." If rules are so important as to prohibit parties from opting out of or changing them by agreement, then this must be because of considerations of public interest. If it were because of considerations of private party interest, then the rule would be subject to differing application in each case depending on party conditions. This does not appear to be the intent of Articles 3(3), 3(4), 6( 2), 8(1), or 11(5)(b), in which the phrase is used. 
located in one or more Member States, the parties' choice of applicable law other than that of a Member State shall not prejudice the application of provisions of Community law, where appropriate as implemented in the Member State of the forum, which cannot be derogated from by agreement.

These two paragraphs create rules for cases that are wholly domestic to a to country other than the country whose law has been chosen, and wholly related only to a country or countries within the European Union, respectively. Under Article 3(3), mandatory rules of a country whose law is not chosen by the parties may be applied whether it is the law of the forum state or of a forum state, so long as "all other elements relevant to the situation at the time of the choice" are located in that other country. Article 3(3) does not require that those provisions of mandatory law be from a Member State of the European Union, but would allow such to be the case. It thus allows the mandatory rules of a country to apply if the contract is purely domestic to that country.

Paragraph 4 of Article 3 prevents private parties from opting out of mandatory provisions of Community law. Apparently because a choice of law clause selecting the law of a Member State would include Community law (which would be applicable in that chosen state), this paragraph specifically applies only when the clause selects the law of a country outside the European Union. The rule applies only when "all other elements relevant to the situation at the time of the choice" are located within the European Union, and only to those mandatory rules that are "implemented in the Member State of the forum." It thus allows the mandatory rules of the European Union to apply if the contract is purely European.

The concept of provisions of law which cannot be derogated from by agreement is also found in Articles 6(2) (generally requiring the application to consumer contracts of the 
mandatory rules of the country where the consumer has his habitual residence) ${ }^{42} 8(1)$ (generally requiring the application to employment contracts of the mandatory rules of the country where the employee habitually carries out his work) ${ }^{43}$ and 11(5)(b) (respecting the application in question of rights in rem in immovable property of mandatory rules of the country where that property is situated). The question of protection of consumers through rules of conflict of laws is discussed further below.

\section{3) Overriding Mandatory Provisions}

The term "overriding mandatory provisions" is found in the text of the Rome I Regulation only in Article 9. ${ }^{44}$ Unlike the language of Article 3(3) and (4), Article 9 does not carve out application of mandatory rules on the basis of purely domestic or purely European cases. Rather, it focuses on the mandatory rules of the forum country and the country of performance.

Paragraph (1) of Article 9 begins by providing a definition of "overriding mandatory provisions:"

1. Overriding mandatory provisions are provisions the respect for which is regarded as crucial by a country for safeguarding its public interests, such as its political, social or economic organisation, to such an extent that they are applicable to any situation falling within their scope, irrespective of the law otherwise applicable to the contract under this Regulation.

Paragraph (2) then provides a rule authorizing the application of overriding mandatory provisions found in the law of the forum:

2. Nothing in this Regulation shall restrict the application of the overriding

\footnotetext{
${ }^{42}$ See also Rome I, supra note 2, recital 25.

${ }^{43}$ See also id. recital 35.

${ }^{44}$ It is also found in the non-substantive exhortations of recitals 34 and 37.
} 
mandatory provisions of the law of the forum.

This is followed by authorization in paragraph (3) for the application of overriding mandatory provisions found in the law of the country of performance of the contractual obligations. Here, however, there is a limitation not found in the paragraph (2) rule. The mandatory rules of the law of the country of performance may be applied only "in so far as those overriding mandatory provisions render the performance of the contract unlawful:"

3. Effect may be given to the overriding mandatory provisions of the law of the country where the obligations arising out of the contract have to be or have been performed, in so far as those overriding mandatory provisions render the performance of the contract unlawful. In considering whether to give effect to those provisions, regard shall be had to their nature and purpose and to the consequences of their application or non-application.

From a U.S. perspective, one must ask if this type of mandatory rule is co-extensive with the concept of public policy applied in cases such as Loucks v. Standard Oil Co. of New York. ${ }^{45}$

\section{4) Restating the Mandatory Rules Provisions and Understanding Their Application}

The result of the provisions in Articles 3 and 9 dealing with "provisions of law which cannot be derogated from by agreement" and "overriding mandatory provisions," considered in terms of what they mean rather than the manner in which they are revealed (or sometimes not so clearly revealed) in the Regulation, seems to be the following:

1) in a case that is purely domestic to a country other than the country whose law has been chosen, the mandatory rules of that other country may be applied (Article $3(3))$;

2) in a case that is purely European, the mandatory rules of Community law may be

\footnotetext{
${ }^{45}$ See, supra note 37 , and accompanying text.
} 
applied (Article 3(4));

3) the "overriding" mandatory rules of the law of the forum may be applied in every case (Article 9(2)); and

4) the "overriding" mandatory rules of the law of the country which is the place of performance of the contractual obligations may be applied when those rules "render the performance of the contract unlawful" (Article 9(3)).

These seem to be rather rational and coherent rules. The first problem is that the structure of the Regulation may result in difficulty understanding them; they could have been more clearly stated.

A further problem is in the application of these rules. It will be interesting to follow that application by national courts and the European Court of Justice. In that process, one hopes that further guidance will be provided concerning such matters as:

1) the overall category of mandatory rules covered by "provisions of law which cannot be derogated from by agreement" and "overriding mandatory provisions;"

2) the dividing line between what is covered by the terms "provisions of law which cannot be derogated from by agreement" and "overriding mandatory provisions;"

3) when a court will and will not exercise the apparently discretionary ability to apply such mandatory rules;

4) the distinction between these two categories of mandatory rules and the public policy limitations on party autonomy found in Article 21, and

5) whether judicial decisions under the Regulation will differ in any significant way from those interpreting and applying the Rome I Convention.

From the U.S. perspective, the concept of "mandatory rules" has never been entirely

clear. ${ }^{46}$ Thus, understanding when certain mandatory rules do and do not apply is a secondary

${ }^{46}$ See, e.g., Patrick J. Borchers, Categorical Exceptions to Party Autonomy in Private International Law, 82 Tul. L. Rev. 1645, 1647-49 (2008). 
step, requiring the initial determination of just what is and is not a mandatory rule. What does seem apparent from a quick glance at practice under the Rome I Convention is that the term "mandatory provision" necessarily results in litigation over what is included, and that the judicial development of that category (at least in a common law Member State) may not provide greater predictability in this regard. ${ }^{47}$

\section{b. Public Policy Generally}

In addition to the mandatory rules provisions of Articles 3 and 9, and the provisions of Articles 6, 7, and 8, protecting weaker parties in specific relationships, Article 21 of the Rome I Regulation allows a court to refuse application of the law chosen by the parties "if such application is manifestly incompatible with the public policy (ordre public) of the forum." This is the ultimate protection of the law of the forum state, and is perhaps the provision of the Rome I Regulation most consistent with U.S. case law. The difference is that, in the United States, the public policy limitation is for the most part a singular limitation, out of which the any protection of mandatory rules or other limitations are drawn.

\section{c. Protection of Specific Categories of Persons in the Rome I Regulation}

While Articles 3 and 9 of Rome I provide public policy limitations on party autonomy through the application of mandatory rules, Articles 5, 6, 7, and 8, carve out specific exceptions to party autonomy based on categories of protected persons or contractual arrangements. Articles

\footnotetext{
${ }^{47}$ See, e.g., DICEY \& MORRIS, CONFLICT OF LAWS, 32-136-32-143.
} 
6,7 , and 8 are of specific interest because they are designed to protect certain classes of persons considered to be the weaker party in the relationship involved in each case. ${ }^{48}$ This is the type of limitation that would have been created in the United States through an new UCC § 1-301, but which has now been specifically rejected.

Article 6 begins by creating a presumption in its first paragraph that consumer contracts will be governed by the law of the country where the consumer has his habitual residence, but this rule applies only if

the professional:

(a) pursues his commercial or professional activities in the country where the consumer has his habitual residence, or

(b) by any means, directs such activities to that country or to several countries including that country, and the contract falls within the scope of such activities.

This effects test approach is quite familiar to a U.S. observer, building on its first application in prescriptive jurisdiction settings, ${ }^{49}$ and reflecting U.S. developments in the jurisdictional sphere by following the logic of U.S. specific personal jurisdiction over legal person. ${ }^{50}$

Paragraph 2 follows by allowing a choice of law clause in a consumer contract, but providing that the clause "may not ... have the result of depriving the consumer of the protection

${ }^{48}$ Article 5(2) provides special rules for contracts of carriage of passengers, limiting the choice of law to the country where:

(a) the passenger has his habitual residence; or

(b) the carrier has his habitual residence; or

(c) the carrier has his place of central administration; or

(d) the place of departure is situated; or

(e) the place of destination is situated.

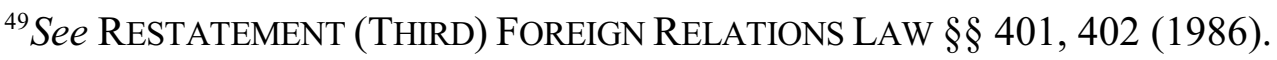

${ }^{50}$ See Ronald A. Brand, Due Process, Jurisdiction and a Hague Judgments Convention, 60 UNIVERSITY OF PITTSBURGH LAW REVIEW 661 (1999). 
afforded to him by provisions that cannot be derogated from by agreement by virtue of the law which, in the absence of choice, would have been applicable on the basis of paragraph 1 . The result is a rather interesting conundrum for the "professional" in the consumer contract relationship. If there is no choice of law clause in the contract, the consumer will get the benefit of the provisions of law designed to protect consumers that are in effect in the country of the consumer's habitual residence. If a choice of law clause is inserted in the contract, then the consumer will get the benefit of the provisions of law designed to protect consumers that are in effect in both the country of the consumer's habitual residence and the country whose law is chosen in the clause. This creates a clear incentive for a merchant or professional not to place a choice of law clause in a consumer contract.

Like an insurance policy written by a company wanting to cover all possibilities in its relationship with the insurance consumer, the Article 7 rules for insurance contracts create the longest single article in Rome I - and like an insurance contract, they are some of the most difficult to read. This is, in part, because of the attempt to incorporate in Article 7 the provisions of the Insurance Directive. ${ }^{51}$ The nuances of this provision are beyond the scope of this discussion. Suffice it to say that Article 7 is designed, at least in part, to protect the interests of the consuming public that purchases insurance, against the stronger bargaining power of insurance companies. Like the Article 6 provisions for consumer contracts, Article 7(3) in

${ }^{51}$ See, e.g., Second Council Directive 88/357/EC of 22 June 1988 on the coordination of laws, regulations, and administrative provisions relating to direct insurance other than life assurance and laying down provisions to facilitate the effective exercise of freedom to provide services, O.J. L 172/1, 4 July, 1988, last amended by Directive 2005/14/EC of the European Parliament and of the Council, O.J. Eur. U., L 149/14, 111 June 2005. For a discussion of the negotiation of article 7, see Lando \& Nielsen, supra note _, at 1710-12. 
particular limits the Member States whose law may be chosen to govern an insurance contract. Unlike Article 6, Article 7 has no provisions for the application of mandatory rules of any country.

Article 8 is the third protective article, rounding out coordination with the corresponding protective provisions of the Brussels I Regulation by extending protection to employees in individual contracts of employment. While paragraph 1 allows parties to such a contract to choose the applicable law in accordance with Article 3, the remaining three paragraphs provide limits on that party autonomy. Those limits are incorporated in paragraph 1 by the statement that a choice of law may not deprive "the employee of the protection afforded to him by provisions that cannot be derogated from by agreement under the law that, in the absence of choice, would have been applicable pursuant to paragraphs 2,3 , and 4 ." Thus, paragraph 2 provides the benefits of employee-friendly mandatory rules in the country "from which the employee habitually carries out his work." If that country cannot be determined, the applicable law is that of the country "where the place of business through which the employee was engaged is situated." Like other provisions for applicable law in the absence of agreement, paragraph 4 provides an escape clause for application of the country with which the contract is more closely connected. The structure of Article 8 will require determination of which mandatory rules will be applied (under paragraphs 2-4), before a rational assessment can be made about the benefits of including a choice of law clause in an individual employment contract.

\section{When and how should choice of law rules be used to protect specific classes of persons?}


So far, our consideration of the questions whether party autonomy in choice of law should be allowed, and what limitations should apply, have focused on what that law is in both the United States and the European Union. The fact that both have a rule respecting party autonomy, and that both supplement that rule with limitations on how far parties may go in choosing the law governing their contractual relationships, does not clearly answer either of these first two questions. In order to do so, however, it is useful to consider the purpose or purposes of the existing rules.

In part, at least, a rule authorizing party autonomy respects the private interests of the parties to any contractual relationship. Limitations based on mandatory rules and public policy respond by acknowledging public interests that caution against unrestrained private choice of law. They are based on a determination that there are social values dictating that private parties should not have complete freedom in defining all of the terms of a legal relationship.

If we are to use rules of private international law to govern the tensions that come from simultaneous protection of private interests through respect for party autonomy and public interests through limitations on party autonomy, this requires that we first determine the threshold at which respect for private interests (party autonomy) should turn instead to the imposition of the public interest (limitations on party autonomy). The structure and complexity of the Rome I rules on party autonomy indicate both the difficulty in determining this threshold and the related question of just which states' public interests we should be attempting to protect.

The search for a clear definition of that threshold raises the related (and very important) question of whether using rules of private international law is the best approach to achieve the protection of the interests involved. The Article 6 rules on party autonomy for consumer 
contracts demonstrate a clear assumption that it is, and provide an opportunity to consider this question, the contours of how it is answered in the Rome I Regulation, and alternative approaches found in the United States as well as in other legal systems.

\section{A. What is the appropriate threshold at which the protection of private interests through allowing party autonomy should give way to public interests in protecting weaker parties in a relationship?}

\section{Rome I and the Rationale for Protection of Consumers}

The limitations on party autonomy contained in Article 6 are based on the belief that consumers "are in need of protection for social and economic reasons, they are considered weak parties." ${ }^{, 52}$ The same rationale applies to the rules on individual contracts of employment found in Article 8. These provisions provide Community consistency in the parallel "protection" of consumers, employees, and insureds found in both the Rome I Regulation on applicable law and the Brussels I Regulation on jurisdiction and the recognition and enforcement of judgments. ${ }^{53} \mathrm{~A}$ comparative approach to the consideration of the Rome I rules seems appropriate in responding to (1) whether the balance struck in these rules properly respects the private interests that drive party autonomy and the public interests that drive the rules limiting that autonomy, and (2) whether private international law rules are the most appropriate legal mechanism for the protection of these competing interests.

\section{Comparing Approaches to the Use of Private International in the}

\footnotetext{
${ }^{52}$ Lando \& Nielsen, supra note _, at 1712.

${ }^{53}$ See Articles _, _, and _ of the Brussels I Regulation,
} 


\section{Public Interest in Protecting Consumers}

The European Union is not the only body that has recently considered the use of private international law rules for the protection of consumers. Others have used this approach, but have adopted approaches differing from that of the EU in defining the appropriate threshold at which the public interest in protecting consumers overrides the private interest of party autonomy.

\section{a. Japan's New Private International Law Rules}

Japan's new Act on General Rules for Application of Laws became effective on January 1, 2007. ${ }^{54}$ That Act, like Article 6 of the Rome I Regulation, includes rules designed to protect consumers through private international law. It does so, however, with differences that are worth noting. The structure of the Act pertaining to party autonomy begins with Article 7, which reads as follows:

Choice of Governing Law by the Parties

\section{Article 7}

The formation and effect of a juristic act shall be governed by the law of the place which was chosen by the party/parties at the time when the act was made.

The term "juristic act" does not translate well, but includes contracts, torts, and other of what we would consider to be types of causes of action. ${ }^{55}$ Like U.S. and European law, this set of rules

${ }^{54}$ See The Act on General Rules for Application of Laws, Act No. 78 of 2006, effective January 1, 2007 ["Japanese Act"]. Reliance here is on a translation made by Professors Masato Dogauchi, Tadashi Kanzaki, Yasushi Nakanishi, Yoshihisa Hayakawa, Aki Kitazawa, and Yuko Nishitani. An additional translation is available in the Yearbook of Private International Law, Vol 8, p. 427, (2008).

${ }^{55}$ For a more detailed discussion of the new Japanese Act from an American perspective, see Ronald A. Brand \& Tabitha Fish, 
thus begins with the recognition of freedom of contract, demonstrating respect for party

autonomy. Like the Rome I Regulation, it also includes special rules applicable to consumer contracts.

Article 11 can be summarized as provides the following rules:

1) A contract between a merchant and a consumer can include a choice of law clause under Article 7.

2) Even with a choice of law clause (and even when private international law rules in the absence of a choice of law clause would lead to other than the law of the state of the consumer's habitual residence), the mandatory rules of the consumer's habitual residence will apply when the consumer affirmatively "expresses his/her will" that they apply. Art. 11(1) \& (3).

3) Even these mandatory rules protections can evaporate, however, if

i) the consumer has gone to the merchant's state and concluded the contract in that jurisdiction;

ii) the consumer has gone to the merchant's state and received complete performance there;

iii) the merchant "is unaware of the location of the consumer's habitual residence and has reasonable ground for such unawareness;" or

iv) the merchant "has misidentified the counterparty as not being a consumer and has reasonable ground for such misidentification." Art. 11(6). ${ }^{56}$

${ }^{56}$ The full text of Article 11 reads as follows:

Article 11

(1) Even if the law governing the formation and effect of a contract (except for a labor contract) that is concluded between a consumer (the term "consumer" as used in this article means an individual who becomes a contractual party neither in nor for the purpose of business) and a business operator (the term "business operator" as used in this article means a juridical person or other association or foundation, or an individual who becomes a contractual party in or for the purpose of business), which is referred to in the following provisions of this article as a "consumer contract", is, according to a choice or change of governing law pursuant to Article 7 or Article 9 respectively, a law other than the law of the place where the consumer habitually resides, the specific mandatory rules in the law of the consumer's habitual residence shall also apply to matters subject to such mandatory rules with regard to the formation and effect of the consumer contract, provided that the consumer expresses his/her will to the business operator to the effect that such mandatory rules should apply. 
(2) If the parties have not chosen a law to govern the formation and effect of their consumer contract pursuant to Article 7, the formation and effect of such consumer contract shall be, notwithstanding Article 8, subject to the law of the consumer's habitual residence.

(3) Even if a law other than the law of the consumer's habitual residence has been chosen to govern the formation of a consumer contract pursuant to Article 7, the specific mandatory rules in the law of his/her habitual residence shall exclusively apply to matters subject to such mandatory rules with regard to the formalities of the consumer contract, notwithstanding paragraphs 1,2 and 4 of the preceding article, provided that the consumer expresses his/her will to the business operator to the effect that such mandatory rules should apply.

(4) If the law of the consumer's habitual residence has been chosen to govern the formation of a consumer contract pursuant to Article 7, and if the consumer expresses his/her will to the business operator to the effect that the law of his/her habitual residence should exclusively apply to the formalities of the consumer contract, the formalities of the consumer contract shall be governed by the law of the consumer's habitual residence, notwithstanding paragraphs 2 and 4 of the preceding article.

(5) If the parties have not chosen a law to govern the formation of their consumer contract pursuant to Article 7, the formalities of the consumer contract shall be governed by the law of the consumer's habitual residence, notwithstanding paragraphs 1, 2 and 4 of the preceding article.

(6) The preceding paragraphs 1 through 5 are not applicable in any of the following cases:

(i) the business operator's establishment which relates to the consumer contract is located in a jurisdiction other than the jurisdiction of the consumer's habitual residence, and the consumer goes to the jurisdiction of the business operator's establishment and concludes a consumer contract in that jurisdiction; except where the consumer has been solicited by the business operator to conclude the consumer contract in that jurisdiction.

(ii) the business operator's establishment which relates to the consumer contract is located in a jurisdiction other than the jurisdiction of the consumer's habitual residence, and the consumer goes to the jurisdiction of the business operator's establishment and receives or is to receive complete performance by the business operator in that jurisdiction; except where the consumer has been solicited by the business operator to receive complete performance to be performed by the business operator in that jurisdiction.

(iii) at the time the consumer contract is concluded, the business operator is unaware of the location of the consumer's habitual residence and has reasonable ground for such unawareness.

(iv) at the time the consumer contract is concluded, the business operator has misidentified the counterparty as not being a consumer and has reasonable ground for such misidentification. 
While the Japanese Act respects private interests through a party autonomy rule in Article 7, Article 11 inserts the public interest of protecting consumers through the application of mandatory rules found in the law of the country of the consumer's habitual residence. It does so, however, in a manner that requires the assertion of the private interest that is considered to be protected in those mandatory rules: the interest of the particular consumer in a particular transaction. The mandatory rules of the consumer's habitual residence will apply only if "the consumer expresses his/her will to the business operator to the effect that such mandatory rules should apply." 57

Unlike the rule found in Article 6 of Rome I that provides for mandatory application of mandatory rules (from both the consumer's country of habitual residence and the law chosen in the contract), the Japanese Act gives the consumer the option of applying the mandatory rules of his habitual residence, but with the choice to instead have applied only the rules found in the chosen law. ${ }^{58}$ This means that two sets of mandatory rules need not be considered by a court unless and until the consumer requests that such consideration apply, and the consumer may make an after-the-fact determination of the benefit of either the single or dual sets of mandatory rules.

The Japanese, in drafting their new Article 7, considered both the European approach and

${ }^{57}$ Japanese Act, supra note _ , art. 11(1).

${ }^{58}$ This is limited somewhat in Article 11(3) \& (4), which provide that the mandatory rules of the country of the consumer's habitual residence govern questions of formation of the contract. Id. art. 11(3) \& (4). 
the possibility of a rule focusing on the law most favorable to the consumer. The reasons for rejecting the European approach found in both Rome I Regulation and its predecessor Rome I Convention has been stated as follows:

If mandatory rules for the protection of a consumer were to be absolutely applied, it would be necessary to determine which rules are more favorable for the consumer, that is, the rules of the chosen law or of the consumer's habitual residence. However, such determination would be very difficult for judges and the parties. Therefore, requiring a declaration by the consumer makes it easier to determine which rules are to be applied. Such a declaration is possible in both extrajudicial and judicial proceedings. No formalities are required. However, the consumer must specify the mandatory rule to be applied. $^{59}$

\section{b. OAS Negotiations}

A different approach has been suggested in discussions within the Organization of American States (OAS) CIDIP process. Both Brazil and Canada have suggested that consumer protection be addressed in rules of private international law. ${ }^{60}$ They have gone a step further than

\footnotetext{
${ }^{59}$ Yasuhiro Okuda, Reform of Japan's Private International Law: Act on the General Rules of the Applicable Laws, advance draft copy of paper to be published in YEARBOOK OF PRIVATE INTERNATIONAL LAW, vol. 8.

${ }^{60}$ See, e.g., Proposal of the Brazilian Delegation - III, After the Preparatory Meeting of Porto Alegre, December 12, 2006 - For the Working Group, Proposal of an Inter-American Convention on the law applicable to some international consumer contracts and transactions. Article 2 of the Brazilian proposal reads as follows:
}

Article 2. General contractual protection - Determination of the Applicable Law

1. If there is no valid choice of law by the parties, the contracts made by the consumer in its country of domicile are governed by the law of this place. Such rule is especially applicable to contracts celebrated at distance, electronically, by telecommunications or by any analogous means of international distance consumer contracting.

2. If the parties have selected the law of the place of celebration, the place of 
either Europe or Japan, however, by suggesting that the court always apply the law most favorable to the consumer. At first glance this approach appears to be more consumer-friendly even than a mandatory rules approach - whether it be the double mandatory rules system in the Rome I Regulation or the optional mandatory rules system in the new Japanese Act. It would require the court to determine the law most favorable, and would not limit the court's consideration to only mandatory rules. What it gains at the litigation stage for the consumer, however, it abandons at the contract formation stage for both parties in terms of predictability. A determination of the law most favorable to the consumer may well hinge on the specific facts that develop in the course of the relationship, leading up to a dispute. Thus, the parties may not be able to determine at the outset just what law will govern their relationship. If predictability in contract relationships is to have any value in the development of private international law rules, then this approach raises significant questions regarding its purpose and effect.

The Japanese rejection of this approach in the adoption of their new law on private

performance or the law of the domicile or seat of the goods or services supplier, such law will be applicable as long as it is more favorable to the consumer.

3. The prior choice of the parties of the applicable law to the contract will be considered more favorably to the consumer:

a) if the chosen law is the one of the consumer's domicile;

b) if the chosen law is the one of the common domicile of the consumer and one of the branches of the professional or goods or services supplier;

c) if the chosen law is the law of the place of celebration or the place of performance and coincides with the law of the domicile or seat of the goods or services supplier.

4. The contracts celebrated by the consumer being outside of his country of domicile are governed by the law chosen by the parties, who may choose the law of the place of celebration of the contract, the law of the place of performance or the law of the consumer's domicile. In case of absence of valid choice, the contracts are governed by the law of the place of celebration. 
international law has been explained as follows:

In the discussion during the drafting process, those who represented voices of judges opposed to the adoption of a rule to the effect that a consumer would never be deprived of protections given in accordance with the law of the place where he/she has his/her habitual residence, which is found in Article 5, Paragraph 2 of the EC Convention on the Law Applicable to Contractual Obligations of 1980 (Rome I Convention). The reason for their opposition was that it would be impossible or very hard for courts to compare, $e x$ officio, which law is more favorable to a consumer. ${ }^{61}$

\section{B. Are private international law rules the appropriate tool for consumer protection?: Another look at U.S. law}

\section{Reconsidering U.S. Limits on Party Autonomy}

In the United States, the common law has not developed such a carefully nuanced approach to conflicts rules for consumer contracts. The same rules that govern choice of law in contracts in general most often will govern choice of law in consumer contracts. ${ }^{62}$ The failure of the 2001 revised version of UCC $\S 1-301$, with its paragraph (e) rule on consumer contracts,${ }^{63}$ to be adopted anywhere but in the Virgin Islands indicates the difficulty of gaining legislative support for such a consumer protection rule in the United States.

This does not mean, however, that the U.S. system has no limits on party autonomy in

${ }^{61}$ Masato Dogauchi, An Overview on New Private International Law of Japan, advance draft copy of version to be published in JAPANESE ANNUAL OF INTERNATIONAL LAW, No. 50 (2007).

${ }^{62}$ But see, e.g., America Online, Inc. v. Superior Court of Alameda County, 108 Cal. Rptr. 2d 699, 710 (Cal. Ct. App. 2001) (rejecting agreement choosing Virginia law because California law provided greater protection for consumers).

${ }^{63}$ The 2001 version of the UCC $\S 1-301(\mathrm{e})$ retained the reasonable relationship requirement for consumer contracts and prevented derogation from mandatory consumer protection rules. See supra notes ___ and accocmpanying text. 
choice of law. But those limits come only in the form of mandatory rules that would apply in the absence of party agreement on choice of law. The Second Restatement only allows limited derogation from mandatory rules that would have been applicable in the absence of a choice of law provision and there is no reference to substantive content of those rules. It does this by beginning with the proposition that the chosen law will govern all matters that could have been resolved by explicit provision of the contract. ${ }^{64}$ It then goes on to provide that the chosen law will also be applied in matters covered by mandatory laws unless there is no substantial relationship with the chosen state and there is no other reasonable basis for the choice, or if the chosen law would be contrary "to a fundamental policy of a state which has a materially greater interest in determining the particular case." ${ }^{95}$

\section{Consumer Protection Outside of Private International Law}

Nor does the rejection in the United States of conflicts rules for the protection of consumers indicate the lack of a public policy to protect consumers. The choice has been made to accomplish this purpose outside the context of rules of private international law. In order to understand this approach it is helpful to gain a more complete understanding of U.S. law on party autonomy by reconnecting the issue of choice of law with that of choice of forum. While the law applicable to questions of jurisdiction can differ substantially from general rules on applicable law, cases in the United States have continued to provide similar analysis of the two matters on the issue of party autonomy. Thus, the U.S. Supreme Court decision in Carnival Cruise Line,

\footnotetext{
${ }^{64}$ Restatement (Second), supra note _, at $§ 187(1)$.

${ }^{65} I d ., \S 187(2)$.
} 
Inc. v. Shute ${ }^{66}$ while dealing with the question of choice of forum, is instructive.

In Carnival Cruise Lines, the Court held reasonable a small print choice of court clause on the back of a cruise ticket that required litigation of all disputes in Florida, even for consumers from the state of Washington. ${ }^{67}$ Justice Blackmun's opinion for the majority acknowledged that "[c]ommon sense dictates that a ticket of this kind will be a form contract the terms of which are not subject to negotiation, and that an individual purchasing the ticket will not have bargaining parity with the cruise line." ${ }^{98}$

The difference in bargaining power of the parties was not, however, the only interest considered by the Court.

Including a reasonable forum clause in a form contract of this kind well may be permissible for several reasons: First, a cruise line has a special interest in limiting the fora in which it potentially could be subject to suit. Because a cruise ship typically carries passengers from many locales, it is not unlikely that a mishap on a cruise could subject the cruise line to litigation in several different fora. Additionally, a clause establishing $e x$ ante the forum for dispute resolution has the salutary effect of dispelling any confusion about where suits arising from the contract must be brought and defended, sparing litigants the time and expense of pretrial motions to determine the correct forum and conserving judicial resources that otherwise would be devoted to deciding those motions. Finally, it stands to reason that passengers who purchase tickets containing a forum clause like that at issue in this case benefit in the form of reduced fares reflecting the savings that the cruise line enjoys by limiting the fora in which it may be sued. ${ }^{69}$

What is interesting here is the court's failure to consider any overriding public policy or mandatory rule that might protect a consumer. In part this may have been because no such rule

${ }^{66} 499$ U.S. 585 (1991).

${ }^{67} I d$. at 594-95.

${ }^{68} I d$. at 593 .

${ }^{69} I d$. at 593-94 (citations omitted). 
existed..$^{70}$ Nonetheless, upholding the merchant-imposed choice of court clause against the consumer was justified on the basis of (1) the merchant's interest in litigating all similar disputes in a single forum, (2) joint interests of predictability, and (3) the general (public) interest of all consumers of such cruises in the lower price that results from upholding such clauses on the basis of the fist two interests.

Applying the rationale of the Carnival Cruise Lines decision to choice of law clauses in consumer contracts, we can discern two very different approaches to consumer protection. On the one hand, the use of private international law rules limiting choice of law (and choice of forum) are founded on the belief that consumers are best protected if, when a dispute arises, they have the advantage of a local law (or the most favorable law) and a local forum. This is the approach found in Rome I (and Brussels I), the new Japanese law, and the Brazilian and Canadian proposals in the OAS negotiations. It is focused on protection of the interests of those consumers who ultimately have disputes with the merchant.

The U.S. approach, on the other hand, views the interests of all consumers similarly situated and begins with the question of how the most consumers can be benefitted. The court in Carnival Cruise Lines concluded that it is reasonable to assume that the general benefit to all similar consumers of a lower price for the cruise ticket outweighs the detriment to the individual consumer having a dispute with the merchant, who is then compelled to take the merchant's choice of law and forum.

${ }^{70}$ The Court did consider the argument that the choice of court clause violated a federal statute prohibiting waiver of liability clauses in contracts for the carriage of persons, but found the statute not to have been applicable. Id. at 595-96. 


\section{Considering the Alternatives}

\section{a. Consumer Protection Through Economic Analysis}

There is a logic to each of these approaches, and it is difficult to make a clear choice of one over the other without empirical evidence that may be difficult to obtain. Each can be described as rather paternalistic, dictating to the consumer a specific result without real consumer choice. The Rome I approach leaves no room for a consumer who would prefer at the outset to receive a better price as a trade-off for taking clauses in a contract that may be considered at the time of contract formation as unlikely to matter. If only one out of a thousand consumers in similar transactions ends up with a dispute with the merchant that would result in litigation, then the U.S. approach results in a benefit to the other 999 similarly situated consumers, each of which receives a lower price for the item purchased. Is it a fair trade-off to make dispute resolution more difficult for one consumer in exchange for providing some reduction in price to 999 other consumers? Or is it a fair(er) trade-off to make dispute resolution easier for one consumer in exchange for a (marginally) higher price charged to 999 other consumers? Either approach represents a policy choice that should be carefully considered by those creating the law.

The U.S. Supreme Court did consider this policy choice in Carnival Cruise Lines, with the majority of the Justices accepting the policy that would benefit more consumers in some small way while placing the limited number of consumers for whom a legal dispute results at a litigation disadvantage. The Rome I Regulation (as well as the Japanese law and Brazilian and Canadian proposals in the OAS negotiations) represents the opposite choice in the consideration of the same trade-off. Under Rome I, prices may be marginally higher for all consumers, but for those who end up with a dispute with a merchant, dispute resolution should be both more 
economical and on more favorable terms.

\section{b Consumer Protection Through Alternative Dispute Resolution}

At this point, a further comparison between Rome I and the U.S. legal system is perhaps useful in order to have a complete picture of the differences in approach. Recent events have highlighted the extent to which the U.S. economy is built on consumer credit. The tendency of U.S. consumers to borrow more and save less has contributed to industry practices that take advantage of that fact. At the same time, however, the substantial level of consumer transactions that are on a credit basis also has provided another mechanism for addressing consumer protection; highlighting a further alternative to the approach found in Article 6 of the Rome I Regulation. Like the Carnival Cruise Lines approach, this one provides the element of consumer protection outside of rules of conflict of laws.

Under the Fair Credit Billing Act, which is part of the Truth in Lending Act, a consumer with a complaint against a merchant in a sale of goods transaction in which payment was made by credit card may raise claims he has against the merchant directly with the issuer of the credit card, as long as (1) the consumer has not paid for the charge, (2) the consumer has made a good faith attempt to resolve the dispute, (3) the consumer has a billing address in the same state or within 100 miles of the transaction (the determination of where a transaction has occurred is made in accordance with applicable state law), and (4) the transaction has a value over $\$ 50 .^{71}$ Thus, a system of alternative dispute resolution is created with the credit card issuer being responsible for considering the claims of the consumer against the merchant. It is the personal

\footnotetext{
${ }^{71}$ Fair Credit Billing Act, 15 U.S. C. § 1666i, and Regulation Z, 12 C.F.R. §226.12(c).
} 
experience of the author that (1) credit card issuers will apply this mechanism even to purchases from merchants outside the consumer's state at a distance of more than 100 miles, and (2) the system can be quite effective for the consumer.

When this system of alternative dispute resolution for consumer transactions is combined with the practice of U.S. merchants of accepting returns of merchandise for full refund of the purchase price, U.S. consumers, in most transactions, have a reasonably strong position in regard to merchants, particularly in transactions for the sale of goods. If one considers the cost of litigation, most consumer sales transactions would not be worth filing an action in court. Thus, trading these protections away for conflict of laws rules that would give to the consumer his local court and local mandatory rules of law, probably would not be a very palatable exchange for most U.S. consumers. The benefit of receiving your own forum and own law in litigation that is not likely to occur would be seen by many to be a rather ephemeral advantage. The opportunity to receive more direct recourse through simple exchange of goods for the purchase price, or through a simple and efficient alternative dispute resolution system provided by the credit card issuer, would be considered by many to be both more efficient and more effective than ostensibly beneficial choice of law (and choice of forum) rules for litigation that may not likely be brought in the first place.

European rules on legal aid, combined with a loser pays rule on costs and attorney fees, may well make litigation a more palatable consumer alternative than it is in the United States, thus making the Rome I rules on consumer contracts more appropriate to the general legal context within Europe. The very different context within the United States, however, means that the incorporate consumer protection in rules of conflict of laws does not necessarily equate to a 
failure to address consumer protection generally. It would be an interesting empirical study to determine informed consumer preference for different combinations of consumer protection rules. In the absence of such information, however, it is difficult to draw fully informed conclusions on which system is better or worse for the consumer. Both have laudable goals. From the U.S. perspective, however, the Rome I approach found in Article 6 would likely be considered by many consumers to be a solution that does not necessarily match the problem - at least as that problem is currently structured in the United States.

\section{A final note:}

The Rome I provisions in Article 6 are justified on the basis of protection of the consumer, but accomplish that protection by effectively giving each consumer the benefits of the mandatory rules of substantive consumer protection law in his or her country of habitual residence. If the consumer protection rules in the EU were uniform, such an approach would be unnecessary, and there would be no need to provide protection through rules of private international law. If one may assume that at least one reason for having such a rule of private international law is that consumer protection varies from country-to-country within the EU, then the result of Article 6 is to provide different levels of consumer protection for different consumers based on their countries of habitual residence. One can argue that if a consumer's country of residence is not willing to provide adequate protection then the EU should not care about doing so on a broader scale. This does not change the fact, however, that this approach to consumer protection is inherently discriminatory within the EU, meaning that the rationale for the rule is applied to benefit some of those whom it is intended to protect more than others in the same class within 
the EU. This raises further questions about whether rules of private international law are the appropriate tool for protecting weaker parties in contractual relationships. 